\title{
His-Tawara bundle in complete AV block complicating double outlet right ventricle with intact interventricular septum
}

\author{
- Antoine A. Verduyn Lunel, Arentje Oppenheimer-Dekker, Caroline L. D. Ch. \\ Bruins, and Alexandra Y. Draulans-Noë \\ - From the Department of Cardiology, the Laboratory of Anatomy and Embryology, \\ - and the Department of Paediatric Cardiology, The State University Hospital, Leiden, \\ The Netherlands
}

A microscopical serial examination of the His-Tawara bundle was performed in a 4-week-old 1 male infant with complete atrioventricular block complicating a double outlet right ventricle with intact interventricular septum.

In this patient a remarkable malformation of the left bundle-branch was found; only the

- initial part had developed, the mid-septal and apical portions were replaced by fibrous tissue. The common bundle, especially the penetrating portion, also showed severe fibrosis, and the

+ AV node moderate fibrosis; the right bundle-branch was least affected. The conduction fibres

- were less clearly striated than normal; the nuclei were often not sharply defined.

The pathological changes in the His-Tawara bundle, which were presumably responsible for the complete AV block, appeared to be a part of other phenomena which might be caused by an inflammatory process, as illustrated by the following findings.

(I) An extensive fibrotic area in close relation to the His-Tawara bundle which started basally

- to the common bundle and showed necrosis and cartilaginous degeneration.

(2) In the septal myocardium outside the fibrotic area giant cells, deposits of calcium, and accumulations of lymphocytes - the latter also in the aortic and pulmonary valves - were found.

The conclusion is drawn that an inflammatory process, started in an early period of embryonic life, presumably before the $17 \mathrm{~mm}$ stage, had contributed to a closure of the interventricular foramen before the aortic orifice was able to reach the left ventricle.

The term 'double outlet right ventricle', - introduced by Witham (1957), means a congenital heart anomaly in which the aorta and

- the pulmonary artery originate separately from the right chamber of the heart. Most of these cases are associated with a ventricular septal defect as described by the majority of authors (Witham, 1957; Neufeld et al., 196ra, b, 1962; Grant, 1962; Morgan et al., 1962; Mirowski, Mehrizi, and Taussig, 1963;

- Rogoff and Anthony, 1966; Venables and

- Campbell, 1966; Dayem et al., 1967; Hollman, 1968; Khattri, Misra, and Dutta, 1968). MacMahon and Lipa (1964), Ainger (1965), and Davachi, Moller, and Edwards (1968) presented cases of this maldevelopment with intact interventricular septum. In contrast to the relative wealth of a haemodynamic and pathological data concerning this malformation, little is known about the aspect and the localization of the His-Tawara bundle.

Titus, Neufeld, and Edwards (1964) described the localization of the His-Tawara bundle in 3 cases of double outlet right ventricle with a ventricular septal defect. Two of these cases without pulmonary stenosis showed an electrocardiogram similar to that seen in cases of persistent common atrioventricular canal defect, while the conduction system had the same localization as in the latter anomaly. The third case with infundibular pulmonary stenosis showed a different type of electrocardiogram but there was the same relation between the ventricular septal defect 
and the conduction system as in the previous 2 cases. The purpose of this paper is to present the aspect and the localization of the HisTawara bundle in a case of complete atrioventricular block complicating a double outlet right ventricle with an intact interventricular septum. The pathological changes in the bundle and the presence of an intact interventricular septum, very unusual in this condition, will be described and discussed in connexion with their presumed origin during embryonic development. The pathological phenomena in the His-Tawara bundle appeared to be a part of other anomalies in the interventricular septum previously described by Oppenheimer-Dekker (1969) who considered these changes as a consequence of an inflammatory process presumably started before the $17 \mathrm{~mm}$ stage of embryonic life. The inflammation might have contributed to a closure of the interventricular foramen before the aortic orifice was able to reach the left ventricle. The embryological and pathogenetic implications of this case are discussed by Oppenheimer-Dekker and GibbenbergerDe Groot (197I).

\section{Case report}

A male infant of 2 weeks was admitted to the Paediatric Cardiology Department of the Academic Hospital of Leiden because of increasing cyanosis and complete atrioventricular block. The weight at birth, which took place spontaneously, was $4200 \mathrm{~g}$. During pregnancy the mother was found to have prediabetes; she had no contacts with any focus of infection such as rubella.

Clinical diagnosis (I) Complete atrioventricular block (Fig. I); (2) persistent ductus arteriosus; (3) ventricular septal defect; (4) right ventricular hypertrophy, pulmonary hypertension; pressure in the pulmonary artery: $60 / 40 \mathrm{mmHg}$; (5) patent foramen ovale.

The day after catheterization an attack of cardiac arrest could not be reversed and the baby died at the age of 4 weeks.

Necropsy (I) Double outlet right ventricle with intact interventricular septum; enlargement of the right auricle and right ventricle, and an obvious hypoplastic left ventricle and mitral orifice. The aortic orifice was located between the junction of the septal and parietal part of the supraventricular crest and the enlarged tricuspid orifice, partially hidden by the commissure between the ventral and septal tricuspid leaflet. The ascending aorta was somewhat narrower than the pulmonary artery of which the orifice was widened to some extent. The origins of the coronary arteries from the ascending aorta, the drainage of the superior and inferior caval veins, the pul- monary veins, and the coronary sinus were normal. (2) Small patent foramen ovale. (3) Narrowed but persistent ductus arteriosus. (4) The right kidney drained into two ureters each with a separate ending into the bladder.

Histological examination The His-Tawara bundle was examined microscopically by means of serial sections. For this purpose the central part of the heart septum including the aortic and pulmonary orifices and a part of the adjacent basally located right ventricular wall was cut horizontally in serial sections perpendicularly to the great arteries from the base to the apex of the heart. The sections, each $10 \mu \mathrm{m}$ in thickness, were stained alternately with haematoxylin-eosin, azan, elastin according to Weigert (1898) and Van Gieson (1889) and with resorcin-fuchsin-ironhaematoxylin-picrin acid-thiazinred according to Hoefsmit (1967).

\section{Results}

On examination of the sections from the base to the apex of the heart it appeared that the plane in which the tissue block was cut was not completely horizontal. Consequently the branching portion of the common bundle was cut first, then the basal part of the right

\section{FIG. I The electrocardiogram; complete $A V$} block.
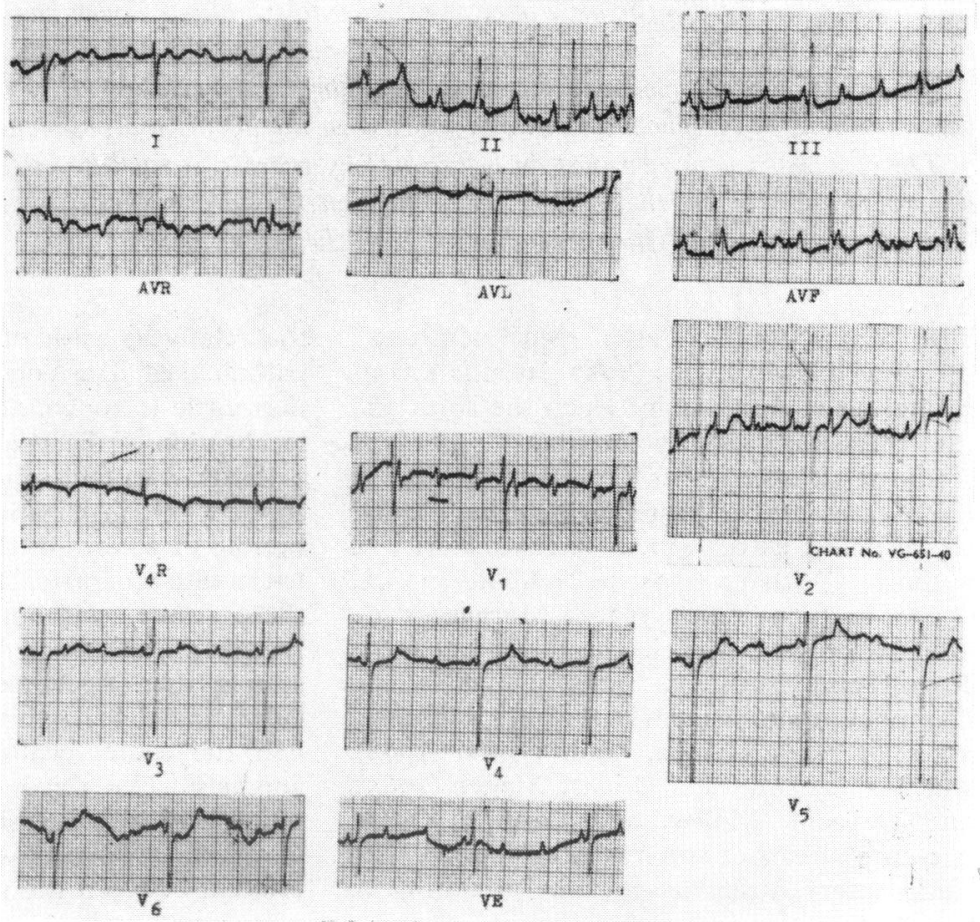
bundle-branch, thereupon the atrioventricular node and the penetrating portion of the common bundle and, last, the descending part of the right bundle-branch.

About $10.6 \mathrm{~mm}$ distal to the origin of the ascending aorta from the right ventricle the common bundle was seen first like a circular structure. On the right of the section the location of the membranous septum was occupied by an area of fibrotic tissue starting basally at the common bundle.

The fibrotic area, located in the central part of the hypertrophied interventricular septum - and ever increasing in apical direction, apappeared to extend like a wedge obliquely to the fibrosed septal endocardium of the left ventricle, always in close relation to the HisTawara bundle. This extensive area showing necrosis and cartilaginous degeneration was previously examined by Oppenheimer-Dekker

- (1969) who also noted that outside this region giant cells, deposits of calcium, and accumulations of lymphocytes - the latter also in the aortic and pulmonary valves - were found in the interventricular septum. The basal side of the fibrotic area extended dorsoventrally from the left of the transition of the atrio- ventricular node in the common bundle to a short distance behind the descending part of the right bundle-branch. The right side of the basal portion of the fibrotic area was located alongside and parallel to the common bundle (Fig. 2).

The left bundle-branch was the most malformed part of the His-Tawara bundle. Only its initial part had developed (Fig. 3); the midseptal and apical portions were replaced by extensions of the fibrotic area. The beginning of the left bundle-branch could be pursued along the fibrotic area, but towards the more apically located septal endocardium of the left ventricle the number of fibres diminished. - Finally, these conduction fibres were overgrown by the fibrotic area while the right bundle-branch was always seen (Fig. 4). Most likely the outgrowth of the bundlebranch was blocked by the fibrotic area. The common bundle showed an obvious fibrosis, too, especially the penetrating portion; the

- atrioventricular node was less fibrosed (Fig. 2) and the right bundle-branch was least affected

- (Fig. 4).

In general the striations of the conduction fibres, the nuclei of which had often indistinct rims, were less clearly defined than normal.

The localization of the His-Tawara bundle - appeared to be more to the right than in the normal situation (Verduyn Lunel, 1964). The

- displacement of the bundle might be a relative one because the interventricular septum was

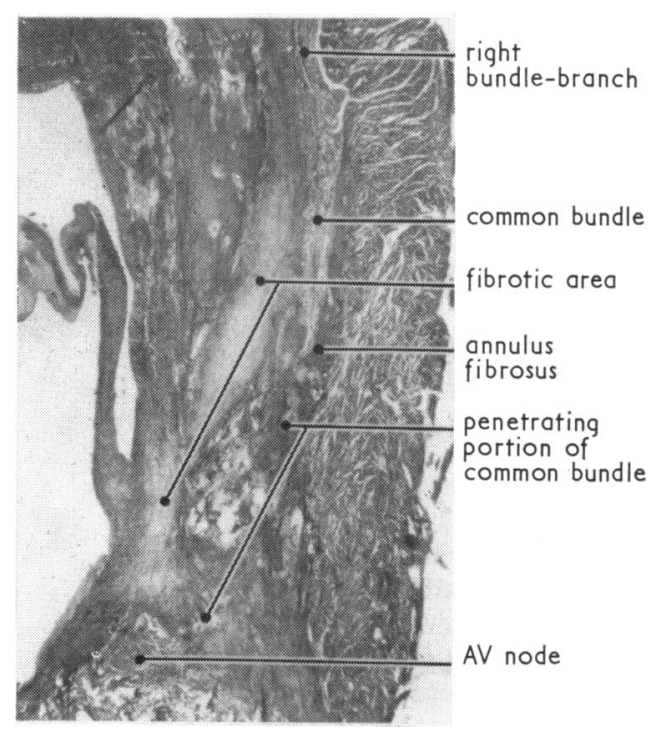

FIG. 2 A section through the basal part of the hypertrophied interventricular septum. The common bundle showed an obvious fibrosis; the $A V$ node a moderate fibrosis. Localization of the fibrotic area alongside and parallel to the common bundle. $($ Azan. $\times 18$.)

approximately three times thicker than normal; on the other hand, it seemed likely that the extensive fibrotic area had contributed to this shift of the His-Tawara bundle. Summarizing, we can state the following important pathohistological phenomena in the HisTawara bundle:

(I) An underdeveloped left bundle-branch existing only in its initial part. The mid-septal and apical portions were replaced by extensions of a fibrotic area which was located in the central part of the hypertrophied interventricular septum close to the His-Tawara bundle. Most likely the outgrowth of the left bundle-branch was blocked by the fibrotic area.

(2) Obvious fibrosis of the penetrating portion of the common bundle; the atrioventricular node was fibrosed to a lesser degree and the right bundle-branch was least affected.

(3) In general, the conduction fibres showed less clear striations than normal; the nuclei were often unsharply defined.

These pathological changes in the HisTawara bundle were presumably the direct cause of the complete atrioventricular block and appeared to be a part of an inflammatory process causing embryonic maldevelopment of the heart (Oppenheimer-Dekker, 1969). 


\section{Discussion}

The embryonic development of the HisTawara bundle was thoroughly studied by several authors (Mall, 1912; Sanabria, 1936; Lev, 1958; Reemtsma, Copenhaver, and Creech, 1958). They all agree that the bundle arises from muscular tissue at the common atrioventricular orifice dorsal to the lower (dorsal) endocardial cushion. In this stage of heart development the musculature of the atrium and ventricle appears to be a morphological entity. The first formation of the atrioventricular node was observed by Mall at the $8 \mathrm{~mm}$ stage and by Sanabria at the II $\mathrm{mm}$ stage. Before the fusion of the lower with the upper (ventral) endocardial cushion at the $12 \mathrm{~mm}$ stage there is an outgrowth of the node and the common bundle to the ventral. The onset of the left bundle-branch develops during the fusion of the endocardial cushions (Lev, 1958). After this fusion the initial part of the right bundle-branch arises while the left bundle-branch has already grown out to the apex. At about the $17 \mathrm{~mm}$ stage it appears that the aortic orifice is able to reach the left ventricle through the interventricular foramen. The latter is thereupon closed by the joining together of the atrial, ventricular, and truncal septa with the endocardial cushions. In this way the membranous septum is formed (Los, 1959, 1963).

In the present case the atrioventricular node, the common bundle, and the right bundle-branch had developed though these parts of the His-Tawara bundle showed different degrees of fibrosis. Before the $12 \mathrm{~mm}$ stage the His-Tawara bundle was able to grow out in a ventral direction and the left bundle-branch could begin to develop. Distal to the initial part of the latter no further conduction tissue was found; the mid-septal and apical portions were absent and replaced by fibrous tissue. Probably the outgrowth of the left bundle-branch towards the apical area had originally started, but its progress was blocked by the fibrotic area which extended within the central part of the interventricular septum obliquely like a wedge from the right, basally to the common bundle, to the apically located left side.

Owing to the fact that the ventral boundary of the fibrotic area in the summit of the interventricular septum was situated dorsally to the descending part of the right bundle branch the outgrowth of the latter was not blocked. This branch was seen in all microscopical sections and appeared only slightly fibrosed.

The dorsal boundary of the wedge-like fibrotic area was found on the left of the tran-

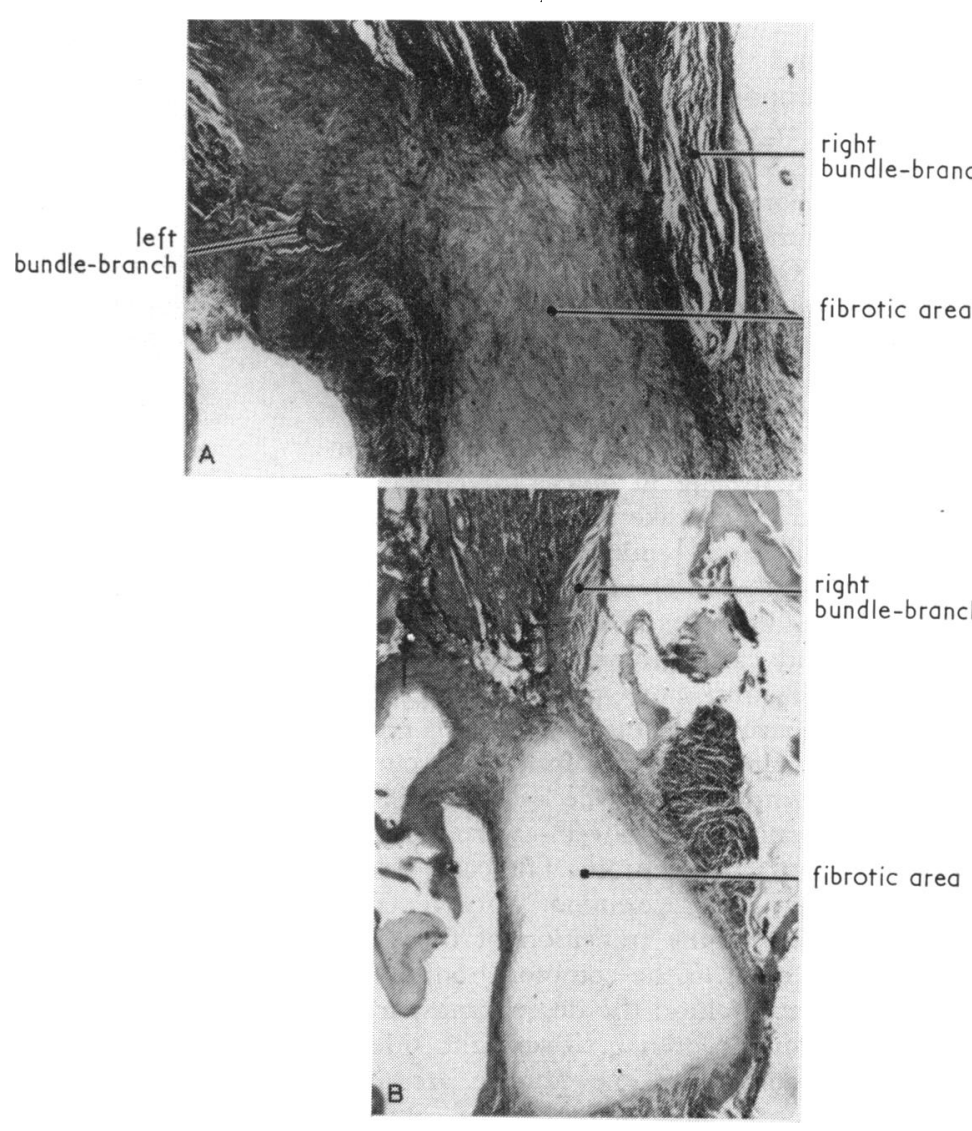

FIG. 3A $A$ section somewhat apical to that on Fig. 2. The initial part of the left bundlebranch on the left, the right bundle-branch on the right of the interventricular septum. Below this level the left bundle-branch was absent. (Azan. $\times 13$.

FIG. 3B $A$ section below that on Fig. $3 A$. Replacement by extensions of the fibrotic area of the left bundle-branch. $($ Azan. $\times 10$.)

sition of the AV node in the common bundle. The node showed ingrowth of fibrotic tissue but it could develop. Also the common bundle was able to grow out though the fibrosis was more severe than that in the node; the right side of the basal portion of the fibrotic region ran alongside and parallel to the common bundle.

With respect to the period during embryogenesis in which an inflammatory process might have started the following data seemed to be important: (I) the membranous septum, formed at about the $17 \mathrm{~mm}$ stage, was found as a part of the fibrotic area; (2) there was failure of development of the left bundlebranch which normally begins at the $12 \mathrm{~mm}$ 
stage, and (3) the other histopathological changes in the interventricular septum. These data indicate that an inflammatory process had probably started before the $17 \mathrm{~mm}$ stage of embryonic life and might have contributed to closure of the interventricular foramen before the aortic orifice was able to reach the left ventricle.

\section{References}

Ainger, L. E. (1965). Double-outlet right ventricle: intact ventricular septum, mitral stenosis, and blind left ventricle. American Heart fournal, 70, $52 \mathrm{I}$.

Davachi, F., Moller, J. H., and Edwards, J. E. (1968). Origin of both great vessels from right ventricle with intact ventricular septum. American Heart fournal, 75, 790.

Dayem, M. K. A., Preger, L., Goodwin, J. F., and Steiner, R. E. (1967). Double outlet right ventricle with pulmonary stenosis. British Heart fournal, 29, 64 .

Grant, R. P. (1962). The morphogenesis of transposition of the great vessels. Circulation, 26, 819.

Hoefsmit, E. Chr. M. (1967). Het sluitingsproces van de ductus arteriosus bij de rat. Een micro-anatomisch onderzoek met gestandaardiseerde kleurmethoden. Thesis, Leiden. Drukkerij Albani, Den Haag. (Summary in English.)

- Hollman, A. (1968). The origin of both great arteries from the right ventricle. In Pediatric Cardiology, pp. 622-631. Ed. by H. Watson. Lloyd-Luke, London.

Khattri, H. N., Misra, K. P., and Dutta, B. N. (1968). Double outlet right ventricle with long survival. British Heart fournal, 30, 569.

Lev, M. (1958). The architecture of the conduction system in congenital heart disease. I. Common atrioventricular orifice. Archives of Pathology, 65, 174.

Los, J. A. (1959). Ontwikkelingsprocessen van de endocardkussens en de septa van het hart. Boerhaave Cursussen voor Specialisten. Zesde Cursus in Cardiologie. Boerhaave Kwartier, Leiden, 2-2e.

Los, J. A. (1963). Recent progress in the study of human heart development. Boerhaave Cursussen voor Specialisten. Achtste Cursus in Cardiologie. Boerhaave Kwartier, Leiden, 78-83.

MacMahon, H. E., and Lipa, M. (1964). Double-outlet right ventricle with intact interventricular septum. Circulation, 30, 745 .

Mall, F. P. (I9I2). On the development of the human heart. American fournal of Anatomy, 13, 249.

Mirowski, M., Mehrizi, A., and Taussig, H. B. (1963). The electrocardiogram in patients with both great vessels arising from the right ventricle combined with pulmonary stenosis. Circulation, 28, I I 6 .

Morgan, J., Pitman, R., Goodwin, J. F., Steiner, R. E., and Hollman, A. (1962). Anomalies of the aorta and pulmonary arteries complicating ventricular septal defect. British Heart fournal, 24, 279.

Neufeld, H. N., DuShane, J. W., and Edwards, J. E. (I96ra). Origin of both great vessels from the right ventricle. II. With pulmonary stenosis. Circulation, 23, 603 .

Neufeld, H. N., DuShane, J. W., Wood, E. H., Kirklin, J. W., and Edwards, J. E. (I96I b). Origin of both great vessels from the right ventricle. I. Without pulmonary stenosis. Circulation, 23, 399.

Neufeld, H. N., Lucas, R. V., Lester, R. G., Adams, P., Anderson, R. C., and Edwards, J. E. (1962). Origin of both great vessels arising from the right ventricle without pulmonary stenosis. British Heart fournal, 24, 393.

Oppenheimer-Dekker, A. (1969). Oorsprong der beide grote arteriën uit de rechter kamer, zonder ventrikel-septumdefect. Nederlandsch tijdschrift voor geneeskunde, 113, 1410.

Oppenheimer-Dekker, A., and Gittenberger-De Groot, A. (I97I). Double-outlet right ventricle without ventricular septal defect. A challenge to the embryologist? Microscopic investigation. Zeitschrift für Anatomie und Entwicklungsgeschichte, 134, 243.

Reemtsma, K., Copenhaver, W. M., and Creech, O. (1958). The cardiac conduction system in congenital anomalies of the heart. Surgery, 44, 99.

Rogoff, J. H., and Anthony, W. (1966). Double-outlet right ventricle with pulmonary valve atresia. Report on a patient surviving to age 25. American Heart fournal, 72, 259.

Sanabria, T. (1936). Recherches sur la différenciation du tissue nodal et connecteur du coeur des mammifères. Archives de Biologie, Paris, 47, I.

Titus, J. L., Neufeld, H. N., and Edwards, J. E. (1964). The atrioventricular conduction system in hearts with both great vessels originating from the right ventricle. American Heart fournal, 67, 588 .

Van Gieson, J. (1889). Laboratory notes of technical methods for the nervous system. New York Medical fournal, I, 57.

Venables, A. W., and Campbell, P. E. (1966). Double outlet right ventricle. A review of 16 cases with 10 necropsy specimens. British Heart fournal, 28, $46 \mathrm{I}$.

Verduyn Lunel, A. A. (1964). De localisatie van het atrio-ventriculaire geleidingssysteem bij normale harten en aangeboren openingen in het septum cordis. (The localization of the atrio-ventricular conduction system in normal hearts and in cases of congenital openings in the septum cordis.) Thesis, Leiden. Drukkerij Albani, Den Haag. (Summary in English.)

Weigert, C. (1898). Ueber eine Methode zur Färbung elastischer Fasern. Zentralblatt für Pathologie, 9, 289.

Witham, A. C. (1957). Double outlet right ventricle. A partial transposition complex. American Heart fournal, 53, 928.

Requests for reprints to Dr. Antoine A. Verduyn Lunel, Department of Cardiology, Academic Hospital, Leiden, The Netherlands. 